\title{
Correction to: Identification of main effect and epistatic quantitative trait loci for morphological and yield-related traits in peanut (Arachis hypogaea L.)
}

\author{
Yogendra Khedikar • Manish K. Pandey • V. Sujay • Sube Singh • Spurthi N. Nayak • \\ Henry W. Klein-Gebbinck • Cholin Sarvamangala • Ganapati Mukri • Vanika Garg • \\ Hari D. Upadhyaya • H. L. Nadaf • M. V. C. Gowda • Rajeev K. Varshney • \\ Ramesh S. Bhat
}

Published online: 1 June 2018

(C) Springer Science+Business Media B.V., part of Springer Nature 2018

Correction to: Mol Breeding (2018) 38:7

https://doi.org/10.1007/s11032-017-0764-z

The published online version of this article unfortunately missed to capture Rajeev K. Varshney as co-corresponding author. There should have been two corresponding authors for this paper (Rajeev K. Varshney and Ramesh S. Bhat). The correct declaration is shown below.

The online version of the original article can be found at https://doi.org/10.1007/s11032-017-0764-z

Y. Khedikar · V. Sujay • C. Sarvamangala · G. Mukri • M. V. C. Gowda

Department of Genetics and Plant Breeding, University of Agricultural Sciences, Dharwad, India

Y. Khedikar · M. K. Pandey • V. Sujay - S. Singh •

S. N. Nayak • C. Sarvamangala · V. Garg ·

H. D. Upadhyaya · R. K. Varshney $(\bowtie)$

International Crops Research Institute for the Semi-Arid Tropics (ICRISAT), Hyderabad, India

e-mail: r.k.varshney@ cgiar.org

S. N. Nayak · H. L. Nadaf · R. S. Bhat $(\bowtie)$

Department of Biotechnology, University of Agricultural

Sciences, Dharwad, India

e-mail: bhatrs@uasd.in

H. W. Klein-Gebbinck

Agriculture and Agri-Food Canada, Beaverlodge Research Farm, Beaverlodge, Alberta, Canada 